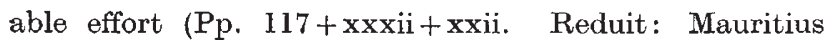
Sugar Industry Research Institute, 1965). However, 1963 was an unfortunate year for Mauritius and the report shows up clearly the great risks involved in tropical agriculture. The area of land under sugar cane was much the same in 1964 as in the previous year, but "A combination of negative factors, dominated once more by the occurrence of two cyclones, were responsible for an overall sugar production of only 520,000 tons, which was below that of the previous year by 24.2 per cent". Among the negative factors stands out the dangerous fact that "Two major diseases, gummosis and leaf scald, which had been totally eradicated from commercial fields, reappeared in epidemic form and are believed to be caused by new and more virulent strains of the pathogens". Only to the continuous work of the Research Institute and its constant search for disease-resistant new cane varieties is it due that "A varietal replacement programme can be designed which should not adversely affect the present sugar potential of the island". The great majority of the report is devoted to the cultivation of the sugar cane and to its diseases and pests; only 15 pages deal with problems of sugar manufacture and a single article (3 pages) mentions an unpromising by-product.

\section{The Linnean Society of London :}

Foreign Members

Dr. E. I. White, president of the Linnean Society of London, announced at the general meeting on April 22 that the following foreign members had been elected: Dr. S. M. Bukasov (U.S.S.R.); Prof. A. Frey-Wyssling (Switzerland); Prof. C. L. Hubbs (United States); and Prof. J. Leonard (Belgium).

Awards and Medals

The following medals were awarded: The $H . H$. Bloomer Award and Medal, to E. C. Wallace; Linnean Gold Medals to Dr. J. Hutchinson and Dr. J. Ramsbottom.

Officers

ThE following officers were elected: President: Dr. E. I. White; Treasurer: The Earl of Cranbrook; Botanical Secretary: Mr. J. P. M. Brenan; Zoological Secretary : Dr. H. G. Vevers; Editorial Secretary: Dr. J. Smart.

\section{Vice-Presidents}

The following were elected vice-presidents for the session 1965-66: The Earl of Cranbrook, Prof. C. T. Ingold, Dr. R. W. J. Keay and Dr. Doris M. Kermack.

\section{Society for Applied Bacteriology : Officers}

AT the annual meeting of the Society for Applied Bacteriology the following officers were elected: Honorary President, Dr. Joan Taylor; Honorary General Secretary, Dr. J. R. Norris; Honorary Meetings Secretary, Dr. Ella M. Barnes; Honorary Treasurer, Mr. G. E. Jones; Honorary Editors, Dr. F. A. Skinner and Mr. G. Sykes; Honorary Publications Manager, Mr. A. H. Walters; Members of the Committee, Dr. F. W. Beech, Miss Vora G. Collins, Dr. Ann W. Cooper, Dr. Christina M. Cousins, Mr. B. M. Gibbs, Dr. Elizabeth M. Harper, Dr. R. M. D. Keddie, Mr. D. A. Shapton and Dr. P. D. Walker.

\section{Perkin Centenary Awards, 1966-1967}

Applications for the award of Perkin Centenary scholarships are invited by the Perkin Centenary Trust. Awards, tenable for one or two years, and renewable for a further year at the discretion of the Trustees, are offered to candidates employed in an industrial firm or other institution concerned with the manufacture or the application of colouring matter, for study at a university or technical college. Two types of award are available, some to the value of $£ 100$, which are to be used in conjunction with a local education authority grant, and others to a value of $£ 400$, which are intended for students whose normal grant, inclusive of fees, would be less than about $£ 300$. Perkin travel grants are also available to teachers concerned with the study of any aspect of the manufacture or the application of colouring matter. Applications for the scholarships must be made by May 1, 1966, and for the travel grants by December 31, 1965. Further information can be obtained from the Secretary, the Perkin Centenary Trust, c/o the Chemical Society, Burlington House, London, W.1.

\section{The Journal of the Franklin Institute Premium}

The Journal of the Franklin Institute has established a special Journal Premium of 1,000 dollars. It is to be awarded annually to the author of the outstanding paper published in the Journal during the preceding year. The award will be presented, in general, to the recipient of the Louis E. Levy Medal. Established in 1923, the Levy Gold Medal is awarded by the Franklin Institute "to the author of a papor of special merit published in the Journal, preference being given to one describing the author's experimental and theorotical researches in a subject of fundamental importance". The Journal of the Franklin Institute was established in 1826 and is the oldest continuing scientific publication in the United States. It accepts contributions in all traditional branches of mathematics and the physical sciences, pure and applied, as well as in interdisciplinary fields or composite sciences that combine the philosophies of two or more disciplines. Consideration for the Journal Premium will be given for the first time to papers published during the calendar year 1965 .

\section{Announcements}

Prof. G. A. Olah, rescarch scientist with the Eastern Research Laboratory of the Dow Chomical Company, has been appointed professor of chemistry and chairman of the department at Western Reserve University.

AN international conference on "Elementary Particles" will be held in Oxford during September 19-25. Further information can be obtained from the Rutherford High Energy Laboratory, Chilton, Didcot, Berkshire.

THE autumn meeting of the Institute of Metals will be held in Grenoble during September 19-25. Further information can be obtained from the Secretary, Institute of Metals, 17 Belgrave Square, London, S.W.1.

A symposium on "Electromagnetic Flow Measurement" will be held in the University of Warwick on September 24. Further information can be obtained from the Administrative Officer, School of Engineering Science, University of Warwick, Coventry.

A Sxmposium on "Chomistry of Plant Pigments", organized by the Phytochemical Group, will be held at the University of Aberdeen during September 23-24. Further information can be obtained from the A. H. Williams Research Station, Long Ashton, Bristol.

AN exhibition of modern packaging methods and machines for the textile industry will be held at the Northern Ireland Linen Research Institute, Lisburn, during September 14-16. Further information can be obtained from the Linen Research Institute, Lambeg, Lisburn, Co. Antrim.

Corrigendum. In the article entitled "Fundarnental Equations governing the Hit Probabilities associated with the Release of a Pattern or Group of Weapons using a Single Aimpoint" by Dr. E. R. Terry, which appeared on p. 1135 of the June 12, 1965, issue of Nature, equation $(10)$, which reads " $(\xi, \eta)=\ldots$. , should read " $f(\xi, \eta)=$ ..."; moreover, equation (21) should read:

$$
S_{j}^{(n)}=\sum_{k=j}^{n}\left(\begin{array}{c}
k-1 \\
j-1
\end{array}\right) Q_{n, k}=\sum_{k=j}^{n}\left(\begin{array}{l}
k \\
j
\end{array}\right) Q_{[n . k]} \cdots
$$

